\title{
Article
}

\section{Viewing Inside the Invisible: African Atlantic visual arts in the 1990s}

\author{
Rice, Alan
}

Available at http://clok.uclan.ac.uk/7362/

Rice, Alan ORCID: 0000-0002-2215-4727 (2013) Viewing Inside the Invisible: African Atlantic visual arts in the 1990s. Slavery \& Abolition, 34 (2). pp. 308324. ISSN 0144-039X

It is advisable to refer to the publisher's version if you intend to cite from the work. http://dx.doi.org/10.1080/0144039X.2013.791180

For more information about UCLan's research in this area go to

http://www.uclan.ac.uk/researchgroups/ and search for <name of research Group>.

For information about Research generally at UCLan please go to http://www.uclan.ac.uk/research/

All outputs in CLoK are protected by Intellectual Property Rights law, including Copyright law. Copyright, IPR and Moral Rights for the works on this site are retained by the individual authors and/or other copyright owners. Terms and conditions for use of this material are defined in the policies page.

\section{CLoK}

Central Lancashire online Knowledge www.clok.uclan.ac.uk

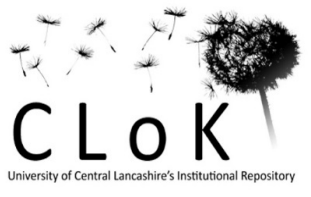




\section{Viewing Inside the Invisible: African Atlantic Art in the 1990s \\ Professor Alan Rice, University of Central Lancashire}

Far too often, despite the two decades since Paul Gilroy’s seminal book, The Black Atlantic, African Atlantic art has been discussed in national silos without the comparative work that enhances our understanding of it. Gilroy's call for cultural historians to treat the Atlantic "as one single complex unit of analysis in their discussion of the modern world and use it to produce an explicitly transnational and intercultural perspective" ${ }^{1}$ is one that I take up here in placing four exemplary African Atlantic artists in the context of a black Atlantic praxis.

A multitude of works about slavery and memory were produced by black artists in the 1990s, but I will concentrate on just a dozen or so works in order to make the critical analysis more than just a survey. Central to discussions about slavery and memory in this period is the maverick African American female artist Kara Walker who burst onto the scene in 1994 and any reckoning of the period must, however reluctantly, engage with her signal interventions. Another landmark in artistic praxis, as well as in political engagement, was Fred Wilson's 1992 Mining the Museum show at the Maryland Historical Society in Baltimore which made a significant commentary on the legacy of slavery through its playful guerrilla escapades. The engagement of different geographical regions in the diaspora is key to a full understanding of African Atlantic art praxis, and the Cuban artist, Maria Magdalena Campos-Pons brilliant installations will show synergies around the circum-Atlantic and illustrate the currency of what we might call a diaspora aesthetics amongst many of the best African descended artists working in the 1990s whilst the work of the black British artist Lubaina Himid will illuminate the importance of European-based black artists to African Atlantic art in the 1990s. 


\section{Breastfeeding Mania in the Hell of Slavery: The Power, Problematics and Perils of Kara Walker's Binary Vision}

It is difficult not to be hugely impressed by Kara Walker's dark vision of the history of the American South. Her large black silhouettes on the bare white walls of American and European art galleries testify to the sexual depravity and violence of a slave past, and to the crude stereotypes it fostered. The 1995 silhouette The End of Uncle Tom and the Grand Allegorical Tableau of Eve in Heaven is a phantasgamoric nightmare inspired by the horrors related in slave narratives and the sentimental genre that followed them, exemplified by Harriet Beecher Stowe’s 1852 novel Uncle Tom's Cabin. In Walker's artwork, Stowe's characters are outrageous exaggerations, with an axe-wielding Little Eva preparing to strike a black toddler, a spike-wielding Topsy threatening Eva and a praying Uncle Tom connected by an umbilical cord to a black baby. Meanwhile, a master figure with a wooden leg skewers a black baby with a sword as he simultaneously copulates with a pre-pubescent girl who seems to be sucked into his body; and this is just the centrepiece. There is ingestation, sadomasochism, defecation and the impregnation of orifices in a debauched and disgusting vision of a debased society. As Celeste Marie Bernier comments:

Her experimental installations relish in an art of bodily appetites as her gorging, swallowing and penetrating black and white bodies provide a space within which her viewers can viscerally relive taboo and untold stories of slavery. Moreover, the sense that the body parts of Walker's protagonists can suddenly 'feed on one another' and belong to her viewers encourages a far more visceral form of identification with slavery than had been created by any other African American artist either before or since. ${ }^{2}$

The piece is stark and terrible, its Manichean vision articulating the symbolic and actual power the slave imaginary still holds in American culture, and Walker shows a certain bravery in visioning it. As she herself says,

I could kind of embody an assessment of stereotypes and cull the art out of them ... the degraded Nigger wench, the blood-drenched lynch mob, I wanted to seduce the audience into participating in this humiliating exercise/exorcise with me. ${ }^{3}$ 
This "humiliating exercise" is a joint enterprise which is described as difficult but necessary for both artists and audiences. Note also Walker's use of language, her desire to "seduce the audience into participating"; this seduction is exemplified in her paradoxical use of the ultra-clean silhouette forms that speak the unspeakable with the clean lines and crafted images of the nineteenth century drawing room. The seductive beauty of her art performs a terrible dark truth in order to exorcise an horrific history. Dominick LaCapra has talked of the “crucial role" in history for "empathetic unsettlement” to enable understanding of the horrific and it is precisely this that Walker essays in her use of stereotypes and the abject to disturb and undermine accepted ideas and historical fabulations that have been passed down by traditions such as the Southern Romance. ${ }^{4}$ Her work is best viewed as an act of "(r)edressing the pained (black) body”, as Saidiya Hartman has discussed:

This pain might best be described as the history that hurts - the still unfolding narrative of captivity, dispossession and domination that engenders the black subject in the Americas. $^{5}$

This "history that hurts" is the clay with which Walker works. But, as Gwendolyn Dubois Shaw discusses, her work has further ramifications, as it refuses the consolation of the redemptory narrative springing from a liberal abolitionist framework. She describes how the work articulates a different, more disturbing vision than had previously been shown:

...Walker, not only visualises the sanctioned histories that can be culled from such a story; she critiques the 'cleansing' of history that abolitionist rewritings performed; she attempts to rememory what is missing, to say what they could not.... Through visual utterance she commands the return of the repressed, the seeing of the unspeakable. ${ }^{6}$

In such a reading, Walker's work provides a necessary, if brutal, corrective to the suppression of the truth about the horrors of slavery. Dubois Shaw uses psychoanalytic language to discuss the way Walker's work enables a coming to terms with a dark past that has been suppressed by both victims and perpetrators, and which chimes with a legion of cultural critics of African Atlantic history who, in the wake of Toni Morrison's ghost story Beloved (1987), have discussed slavery in terms of spectrality. As Hershini Bhana Young 
contends, "[t]he African diasporic ghost story is thus, quite literally, about the truth concerning oppression coming back, the return of the repressed and suppressed." ${ }^{7}$ This Gothic element in Walker's work is emphasised by the dark silhouette forms and by gratuitous violence, supernatural flying, bodily dismemberment, disability and malfunction. Central to Walker's vision, however, is the black body in its historical role as plaything for the Southern slave master and as selfless succour to white children. As Dionne Brand discusses, these bodies are deeply imbricated in the psyche of slave-owners and their descendants as "projections of the[ir] sensibilities, consciousness, needs, desires and fears". ${ }^{8}$ She continues:

The body is the place of captivity. The Black body is situated as a sign of particular cultural and political meaning.... as if those leaping bodies, those prostrate bodies, those bodies made to dance and then to work, those bodies curdling under the singing of whips, those bodies cursed, those bodies valued, those bodies remain curved in those attitudes. They remain fixed in the ether of history. ${ }^{9}$

Walker is attempting to disturb and unravel the fixtures and fittings of an American, and especially a Southern, history, to disturb and disrupt "the ether of history”, but this is not just an abstract exercise that will help re-imagine a past: her project is to exorcise this past because of its influence in the here and now. As Brand discusses, African Americans are still under the threat of a racial imaginary that limits and oppresses the whole society. She describes how these black bodies “...leap onto the backs of the contemporary - they cleave not only to the collective and acquired memories of the descendants but also to the collective and acquired memories of the other. We all enter those bodies.”10

This is both a significant strength of Walker's work and a major problematic: that it does not just disclose a tortured history, but projects these images and their disturbing ideologies into the maelstrom of contemporary racial signification and the politics of race. Much of the criticism of her work, exemplified by black artists Bettye Saar and Howardena Pindell, and collected in the sclerotic Kara Walker - No, Kara Walker - Yes, Kara Walker -? (2009) is 
concerned with the way the stereotyped images of African Americans play to a racist agenda and is best summed up by one of the many bloggers who reacted to the 2007 exhibition at Whitney Museum in New York, My Complement, My Enemy, My Oppressor, My Love. Christopher, a 26-year old African American, says:

Walker's work does not subvert the white supremacist imagination of blackness but rather re-presents it in the tangible here and now, bows to the hegemonic forces and makes offerings of eagerly copulating slave women, debased pickaninnies and confused buckoons [...] Walker's work disturbs me because while it does present a horrifying, grotesque, epic vision of this country's foundation it simultaneously hints that it is all o.k., that blacks are just as complicit as whites and that these horrors were somehow, in part, self-extracted. ${ }^{11}$

This is a powerful and emotional critique, that in my opinion becomes more compelling as Walker's work has failed to progress from its relentless concentration on the debased, stereotyped images of blackness that suffuse this early work. There is a fine line between presenting stereotypes in order to subvert them and invoking them so often that they become everyday, normalised even, and this is a central problematic in Walker's work.

However, in discussing her work from the 1990s I do not want to be distracted into a discussion about reception or how she failed to develop beyond obsession with these images, even though I acknowledge the importance of these debates. Rather, I want to examine a specific element of The End of Uncle Tom and other manifestations of it in her work as a way to critique Walker's praxis with a historical lens. In one corner of this installation there is a compelling image that reflects the lives of women in slavery, an image of breastfeeding women. Walker herself points to the importance of such images in her work when she discusses the correlation between breastfeeding, weaning and history:

History. My constant need to suckle from history, or through history could be seen as a seemingly endless supply of mother's milk refreshed by the big black mammy of old. For myself I have this constant battle - this form of weaning. It's really a battle I apply to the black community as well, because all of our progress is predicated on having a very tactile link to a brutal past. ${ }^{12}$ 
This is a powerful self-analysis, shown by Walker's constant reiteration of themes from the slave past in her work over two decades. More than this, her description shows a compulsion in the suckling that she projects onto the larger African American culture and includes here as an important image for the understanding of the installation and its wider meaning. Her suckling from history could even be said to be literally portrayed in this image in Uncle Tom... A slave woman stands bare-breasted whilst a full grown woman breastfeeds from her; she too is bare-breasted and is breastfed by a woman who emerges from under the first woman. The effect is like a Russian doll with different characters repeating the action almost inside each other. This reflects Walker's discussion above and how the repetition of action and its circularity is a key trope of the history of blacks in slavery. Meanwhile, a slave child is straining to reach a breast to satiate his hunger, but unable suckle because of the frantic feeding activities of the three women who ignore him. This image has been discussed by Dubois Shaw who sees in it “a racialized transgression of sexual and gender roles”, for “the women have neglected their duties as slaves and are now nursing each other” in order to assuage their erotic desires. ${ }^{13}$ Shaw's discussion of the breastfeeding mania foregrounds it as a lesbian activity, a radical alterity in the context of a slave system that allows no such privatised sexual satisfaction. Moreover, she describes it as reflecting the absence of maternal satisfaction during slavery:

The depiction of sexual self-reflexivity in Walker's scene may be read then, as an institutionally imposed mother-hunger.... As they suck on and suckle each other, the history of slavery is passed between them. It visualises a desire for the lost maternal nurturing that was systematically withheld under the system of slavery, rather than the breast that is withheld by a "bad" mother. Walker's women live in the immediate moment in which their needs are being fulfilled. The beginning of their sexual experience is in fact the end, as what had so often been withheld from their grasp is finally released into it. The child, however, will simply have to wait. $^{14}$

This radical image of slave self-gratification and refusal of the maternal role challenges the stereotypes of the faithful mammy and the slave harlot at the master's beck and call. Rather than being the nurturer of white and black babies, these women nurture themselves. I 
agree with Dubois Shaw that this image has radical connotations in its reaction to the slave past; however, the problematic of the work is its relentless furthering of a binary agenda that allows little room for nuance and sometimes this makes it beholden to a frankly reactionary agenda. I would like to pursue this argument around two other images of breastfeeding, this time by and of grown men. The first is Walker’s 1995 image Before the Battle (Chickin' Dumplin'). ${ }^{15}$ Here a topless black woman is shown breastfeeding a kneeling Confederate soldier. His action of feeding from her makes her drop the chicken bone she is feeding on, illustrating that the needs and desires of white Southerner slaveholders always come at the expense of their black slaves. His adult breastfeeding of her is a throwback to the nurturing he would have received from a black wet-nurse when he was growing up. Walker portrays him as having never grown up beyond this infant state and undermines his martial status through his childish dependency on this black breast milk. The Confederacy is shown to be dependent on slavery even at this moment of military endeavour for self-determination. As with the image in Uncle Tom... Walker here cleverly highlights aspects of historical Southern culture that are often hidden by Romantic apologists for the South, albeit through an image of black as well as white abjection.

If this image of the black breastfeeding of a white adult reflects a radical response to the elisions and mythologies of white Southern history, the 1996 gouache drawing John Brown evens the score by visioning the limitations of white abolitionist mythology and martyrology. ${ }^{16}$ Brown was sentenced to death for his part in the 1859 multi-racial raid at Harper's Ferry, Virginia, which attempted the violent overthrow of slavery. Walker's work is a direct response to images of Brown's walk from the jail to the gallows, which showed him leaning down and blessing a baby presented by a submissive black woman. Walker signifies on this image by presenting a semi-naked Brown being suckled hard by a black baby carried in the arms of a proud black woman staring straight ahead. The baby stretches at his poorly 
lactating nipple, illustrating the poor meal any black would get from such an offering. Brown, in pain from the attentions of the infant, stares away from the mother and child. I believe this image shows the limitations of Walker's political vision. If we compare it to the breastfeeding Confederate soldier we are encouraged to split white men into two camps: those slave-supporters who suckle on a slave system which supports their polity or those white abolitionists whose gift is merely the weak milk of human kindness which does not satisfy. Such a binary opposition does no service to the memory of a radical politics that pursued a multi-racial clash against the slave power, and presents a decidedly nihilistic vision. Marcus Wood, in his astute polemic against liberal white guilt, The Horrible Gift of Freedom: Atlantic Slavery and the Representation of Emancipation (2010), describes the manifestation of abolition as a gift from white patrimony as "a brilliantly constructed aesthetic system for the control of white guilt and black suffering and for the disguise of white culpability and black outrage”. ${ }^{17}$ Walker’s depiction of Brown as lactating martyr could be said to embody such a system. However, it is the image of Brown as constructed by post-war Anglo-American artists that she presents, completely overlaying the actual historical Brown who for all his faults pursued a raging, violent, multiracial reaction to the persistence of slavery that does not deserve such a response from one who, according to her own testimony, has suckled from history. As Toni Morrison has said,

.... [there is] a necessity for remembering the horror, but of course there's a necessity for remembering it in a manner which can be digested, in a manner in which memory is not destructive. $^{18}$

Unfortunately, Walker's powerful and disturbing art does not allow for such a digestible memory, and becomes at its worst destructive, working against radical colour-blind solutions to white supremacy. In light of the discussion above and of Morrison's comment, Walker's vision can be seen as brilliant but partial, didactically fierce but politically naïve: a binary 
vision of a history that needs anger and polemic, but cannot afford to be so blown away by that to misread the past it suckles from.

\section{Fred Wilson Mines the Museum: Guerrilla Memorialisation in the Belly of the}

\section{Beast}

If Kara Walker's interventions amounted to a suckling from the past, Fred Wilson was engaged in a different, if related, activity: mining the past. In 1992 he constructed an exhibition at the Maryland Historical Society (MHS) in Baltimore that helped to change the way black artists worked with museums. Rather than being unconsidered servants to the curators, he posited, and helped to create, a role for them as brokers between the institution and old and new audiences. His praxis was explained by the title for his exhibition:

I called the installation 'Mining the Museum' because it could mean mining as in a gold mine - digging up something rich with meaning - or mining as a landmine - exploding myths and perceptions.... Some artists use powdered pigments, empty canvasses, clay or just a pile of stuff - but this museum was raw material to me. It had everything. ${ }^{19}$

Wilson mined the 'raw material' of the museum for objects that he could mould to tell hitherto silenced stories from Maryland's history. For example, he uses a succession of plinths to critique the version of history the collection has traditionally foregrounded. The plinth is key to the way the exhibitionary space gives hallowed status, adding weight to those who are raised up. Wilson, mining in the stores, found numerous examples of white historical figures to display, but a dearth of black figures; even Maryland black heroes who were conspicuous by their absence. His display riffs on this absence in the museum, and by extension in the wider historical record. In the centre is a globe used as a trophy in a local 1922 advertising competition which has carved on its surface the word 'TRUTH' which is used as a playful ironic device by Wilson to foreground his polemical purpose: where is the truth in a collection that marginalises its black heroes? To the right are three plinths with 
marble sculptured heads of Enlightenment men, Southerners Andrew Jackson and Henry Clay and the French Emperor Napoleon Bonaparte, all of whom were slaveholders and supporters of slavery in their political roles. To the right are three empty plinths, labelled Harriet Tubman, Frederick Douglass and Benjamin Banneker, all prominent black Marylanders whom you would expect to find memorialised in a state museum. Wilson's method, which he uses here and throughout the exhibition, is to dialogise what is highly visible in the collection with less visible or even invisible objects in order to highlight elision both wilful and accidental. As he himself says,

...juxtaposition is one way of unlocking [history] without a didactic tone - allowing the objects to speak to each other. I feel that there is a dialogue between objects sometimes subtle dialogue, sometimes pronounced dialogue, depending on how diverse the objects are and depending on who is seeing them too. ${ }^{20}$

His juxtaposition here unlocks the racialised history the museum has been complicit in and his action could be said to be a guerrilla memorialisation that intervenes in the institution to enable more inclusive histories to be uncovered. Such guerrilla memorialisation strategically interrupts normalised exhibition space to work against traditional historiography and awaken the ghosts that have hitherto lain dormant. ${ }^{21}$ Here, the empty spaces on the plinths do memory work, alerting the audience to their absence in the context of the plenitudinous, object rich museum context. Maurice Berger has discussed cogently how such interventions work:

... [they] construct an immediate phenomenological space in which the very objects and people wronged by the museum are literally placed centre stage. Acting as surrogates, as ghosts of the human beings that stand behind them as creators or victims, these objects ask questions that directly challenge the present-day status of the museum. ${ }^{22}$ In challenging the museum, Wilson creates a series of installations that have their own power to shock, emotionally engage and aesthetically please the viewer. He is a guerrilla worker, a ghost in the curatorial machine, undermining its hegemonic power and questioning its widely accepted truths. Wilson's introduction of the ghostly presence, the spectral can be 
compared to Walker's praxis discussed earlier. His empty plinths here and manipulation of objects elsewhere in exhibition could be seen as,

spectres, [crucibles] for political mediation and historical memory that enables us to rethink the relationship between knowledge and power, between an authorized and a vernacular witnessing of racial injury itself. ${ }^{23}$

In envisioning a slave presence, Wilson invokes the ghostly to critique a museology

stymied by its historical attachment to an empiricism that elides narratives whose written

history is marginalised and not recorded. As Hartman contends:

The effort to "brush history against the grain" requires excavations at the margins of monumental history in order that the ruins of the dismembered past be retrieved, turning to forms of knowledge and practice not generally considered legitimate objects of historical inquiry or appropriate or adequate sources for history making and attending to the cultivated silences, exclusions, relations of violence and domination that engender the official accounts.... the effort to reconstruct the history of the dominated is not discontinuous with dominant accounts or official history, but, rather, is a struggle within and against the constraints and silences imposed by the nature of the archive... ${ }^{24}$

And, we might add, “the nature of the museum”. Mining the Museum illustrates Wilson's radical praxis, showing how he foregrounds objects in order to "reconstruct the history of the dominated" and to alert his audience to the lacunae that he seeks to alleviate. One of his most astute installations in Mining the Museum is 'Cabinetmaking', a faux Victorian drawing room with four elegant empty easy chairs facing the city's nineteenth century whipping post. As Berger describes, Wilson's juxtaposition animates history, as audiences are encouraged to use their imagination to fill these chairs and the whipping post with historical characters from different subject positions, classes and races. Such objects are not normally arranged in the same museological space and Wilson enacts a guerrilla memorialisation that illustrates that the leisure of the rich is procured at the expense of labour, both free and unfree. He is involved in no less than an attempt to remodel the relationship of audiences to museums, to expose the seeming objectivity of the traditional display and rub it against alternative histories. This is his guerrilla memorialisation in the belly of the beast that is the traditional museum. He describes this process: 
At first you went through the museum and encountered a regular, objective kind of environment about art and history in the United States. But through the context of my installation you began to see things differently. All of a sudden, the rest of the museum seemed very much someone's point of view about history and culture. Not necessarily unscholarly - just not monolithic. If you take away from my installation the idea of the museum's inherent subjectivity, that the institution is not entirely objective and that it is made up of various people's desires, biases, and assumptions about the world, you can rethink your own relationship to the museum. The museum becomes a real place, not so different from what you know outside the edifice. Its seamless ability to encourage passivity among its visitors is shattered and is replaced by an actively engaged, thinking, feeling audience. ${ }^{25}$

In a sense, what Wilson asks the audience to do is to move from what Barthes would call a 'readerly' approach to the museum and instead adopt a 'writerly' approach; that is, to move from a passive acceptance of the given narrative to an active engagement so that the audience does not passively read the museum, but rather reads against the grain of its narrative, complicating it and pulling out narratives obscured beneath its seemingly objective rendition of historical fact. Wilson's practice can be compared to that of memory artists of the Holocaust, as discussed by James Young, whose interventions

...[a]re not meant to instruct per se, but to throw previously received instruction into question. Their aim is not to reassure or console but to haunt visitors with the unpleasant - uncanny - sensation of calling into consciousness that which has been previously repressed. ${ }^{26}$

Wilson's installations have ramifications in the present as well as in depiction of the past. Through his art Wilson dialogises the present with interpretations of the past to discomfort a nostalgia for the past which is not only inherently conservative, but also dangerously complacent. Like bell hooks, he wants to achieve a "politicization of memory that distinguishes nostalgia, that longing for something to be as it once was, a kind of useless act, from that remembering that serves to illuminate and transform the present." ${ }^{27}$ The major triumph of Mining the Museum is not just that it refigures the past, but also that it makes the objects speak to and influence contemporary racial realities. 


\section{Visioning Black Atlantic Memories Through Female Labour: The Translucent and the Redemptive in the work of Maria Magdalena Campos-Pons}

If, as we have seen, Kara Walker suckles from history and Fred Wilson mines it, Maria Magdalena Campos-Pons, a Cuban artist now resident in the United States, could be said to bathe in its watery depths. Her large body of work over the last twenty-five years continually investigates the meaning of migration and the legacies of the transatlantic slave trade. Jean

Fisher has discussed the way "the experience of cultural trauma and remembrance animated diasporic artistic practices” and Campos-Pons’ work is testimony to this collision of traumatic legacy, memory and forgetting. Fisher continues:

In confronting the articulation of the 'what' and 'how' by reference to the historical archive and individual testimony, black diasporic artists reassembled a body to be mourned from the fragments of the past, to produce a radical revision of our representations of historical process, national culture and the construction of subjectivities. $^{28}$

It is this subtle collusion of historical and testimonial fragments that distinguishes the work. Campos-Pons’ altar-like installations from the 1990s used both archival sources and family remembrance to produce art works that celebrated and mourned her ancestors from Africa and the Caribbean. Her 1998 piece 'Spoken Softly with Mama', first shown in the National Gallery of Canada, Ottawa, is exemplary. The space is dark, with images projected onto seven upright forms. These are shaped as ships' hulls, tombstones, coffins and/or ironing boards, illuminating the multiplicity of the black Atlantic world Campos-Pons is summoning, where slaves are carried across oceans in ships to perform domestic labour, but also bring with them their culture including elements of religion such as Santeria, exemplified here by the altar-like form of the installation. Sally Berger calls this "a magnificent altar in visual and poetic praise of the women's fortitude that nourished family and friends following the end of slavery”. ${ }^{29}$ The images projected onto the upright forms are life-sized monochrome 
photographs of female ancestors stretching back to the nineteenth century that give faces and hence identities to these usually nameless and marginalised domestic labourers. The other three projections are of bodies walking or crouching with a watery backdrop. Laid out in front of these upright forms are dozens of translucent pate de verre irons which are placed around trivets arranged in flower-like patterns, illustrating the female domestic space of slavery and post-slavery poverty in the diaspora as key to the working of memory.

Here objects that are usually anchored in the repetitive drudgery of the domestic enclosed space of the home are transmogrified by being in new spaces and even have a mobile impetus. The translucent irons, "like foam floating on the sea, inanimate objects charged with life”, ${ }^{30}$ are imagined as being parts of flotillas on the ocean carrying memory round the circum-Atlantic space, circling islands of trivets transformed into things of beauty. Out of the domestic detritus of labouring poverty, Campos-Pons makes redemptive forms that posit mobility and escape. What is important here though is that black Atlantic movement is dependent on the workings of ancestral memory and remembrance. What are constructed here are "diasporic landscapes of longing”" ${ }^{31}$ that connect the migrant subject to her multiple pasts in Cuba and Africa. Private and public memory is combined here by Campos-Pons, for whom memory is a fragile and translucent concept:

I am interested in memory, because memories are like little panes of glass. They are fragile, they are vulnerable; they are stable and resistant. So I always think of, and always talk about, memories as being as much about fiction as they are about reality. I always say that I know that memory is a slippery place ... I want to use the past metaphorically... ${ }^{32}$

The work holds together by foregrounding private memory to tell a public story of dispersal in the wake of trauma. Her semi-fictional memories can fill the gaps in the historical record which have been obliterated by the destructive histories of slavery and colonialism. In this way her praxis brings forward memory as a tool against the majority culture's forgetting of a traumatic past. Paul Ricoeur reminds us that: 
Historical knowledge perhaps has never, in fact, stopped dealing with these visions of historical time, when it speaks of cyclical or linear time, stationary time, decline or progress. Will it not then be the task of a memory instructed by history to preserve the trace of this speculative history over the centuries and to integrate it into its symbolic universe? This will be the highest destination of memory, not before, but after history. ${ }^{33}$

Ricoeur here proposes that memory need not be the raw material that makes history, but is capable of being that which helps to bring enlightenment anterior to the historical narrative to help fill the gaps traumatic histories engender. Campos-Pons posits memory as mobile, circular, non-linear, working with history but no prisoner of it. In talking of her work 'Threads of Memories' (2003) she describes a praxis using memory that also seems to be present in her earlier installation:

My work...is an attempt to comprehend and perhaps to represent the mechanics of memory, the traces of time that constitute the materiality of memory and those aspects that permeate a personal or collective history, inscribed on objects, place and recollections.... I think that memories first are the circuits of the past as they weave themselves on the present, so when talking about memory in my work I want to locate it not in the past but in its transient quality, in its permeability. Is memory horizontal, past, present and future, vertical? It is Feminine. It is that solid line surrounding everything and everywhere. But also memory is selective, not all is recollected. ${ }^{34}$

Key to this riff on memory is her discussion of it as transient, selective and permeable. These are the aspects of the memorial sublime that 'Softly Spoken with Mama' expresses through the interaction of its various objects. The watery past, the cartographical imagination and the cosiness of family space are juxtaposed and layered with the history of enslavement and diasporic trauma to create a memorial space that works in many dimensions. As CamposPons attests:

I am interested in the private against the public, the small account against the large in everyday life, the particular experience, the insignificant others. I am using my family words to inscribe the stones that have only been used to tell the stories of heroes. Yes, memories are fragile, but they are strong too. ${ }^{35}$

Her installation promotes a new group of heroes whose memory should be inscribed on stones, the often anonymous diasporic Africans who survived all that slavery and racism threw at them, the continuity of whose narratives is established by the work itself. Stuart Hall 
has talked of the "ruptures and discontinuities which constitute precisely the Caribbean 'uniqueness”' and this is what is so brilliantly imagined in Campos-Pons' oceanic installation. In fact it promotes a version of Caribbean cultural identity, a "matter of 'becoming' as well as of 'being”' that chimes with Hall's conception outlined in his essay 'Cultural Identity and Diaspora':

[Cultural identity] belongs to the future as much as to the past. It is not something which already exists, transcending place, time, history and culture. Cultural identities come from somewhere, have histories. But like everything which is historical, they undergo constant transformations. Far from being eternally fixed in some essentialized past, they are subject to the continuous "play" of history, culture and power. Far from being grounded in mere "recovery" of the past, which is waiting to be found, and which when found, will secure our sense of ourselves into eternity, identities are the names we give to the different ways we are positioned by, and position ourselves within, the narratives of the past. ${ }^{36}$

Hall's conception of identities that are not fixed by the operation of a traditional notion of an unchanging history provides a conceptual background to Campos-Pons' imaginative evocation where the very signs of domestic servitude in a confined space are transformed by the operation of memory and diasporic consciousness into a theatre for mobility and transformative redemption. For Campos-Pons, like many other African Atlantic artists,

The past never ends though but becomes transformed. The transformative labor of memory folds the past and present into each other as it registers multiple temporalities and experiences. ${ }^{37}$

\section{Reclothing the Slave Body and Making Memorials From Its Waste: Lubaina}

\section{Himid’s Black Atlantic Vision}

Like Campos-Pons, Lubaina Himid is engaged in work that disrupts linear chronologies and explores extended cartographies to fully express African Atlantic diasporan realities in the wake of the transatlantic slave trade. She emerged as one of an important group of black British artists whose work in a number of landmark exhibitions in the 1980s constructed a space for a radical, questioning agenda across issues of race, class and gender. These artists 
included Keith Piper, Isaac Julien, Eddie Chambers, Ingrid Pollard, Maud Saulter and Sonia Boyce, several of whom used their work to interrogate the legacy of slavery. Himid’s sequence Revenge, exhibited at the Rochdale Art Gallery in 1992, included sketches, finished works, installations and text that built into a commentary on the slave trade and its legacies. The title is explained by Himid as being a reference to black people's survival despite the vicissitudes of slavery, imperialism, oppression and a racist art establishment. She says, "[t]he revenge is still being here, the still being visible, despite the challenge of that." 38 Himid's landmark piece from that exhibition, 'Between the Two My Heart is Balanced', has become, because of its acquisition by the Tate, a signal piece in terms of black British art and feminism. As Himid herself told me:

I think I made a political painting there, and ... [the Tate] use it for their own ends politically.... it's used as a conversation piece between the Tate - the establishment and the audience, especially when the audience is 'other'. [Meanwhile] I was trying to paint myself and my compatriots, my fellow black artists, if you like, into the history of British painting. And I'm trying to make a comment about how European artists have hijacked some of our African and Caribbean imagery, our bodies and all the rest of it, and I've hijacked some of it back. ${ }^{39}$

In her dramatic portrayal, two African women in native dress sit in an open boat midocean, an African cloth design between them, "tearing up navigation charts”. ${ }^{40}$ This utopic, calm scene depicts the survival of African culture despite the intervention of slavery and colonialism. The women take control mid-ocean consigning Western charts which have been the bane of the enslaved blacks - crucially allowing Europeans to steer more accurately between African and American slave ports - to the depths of the sea. As Himid explained, "the painting is a musing on what would happen if black women got together and started to try and destroy maps and charts - to undo what has been done.”41 Her centring of black women in this image of the black Atlantic signifies on the masculinist nature of many interpretations of the history of African resistance to slavery and colonialism, performing a needful corrective to such chauvinism. Speaking of quilting, Jacqueline Nassy Brown 
discusses how "the cosmopolitanism of women and families would be lost in a sea of narratives that privilege oceans as sites of global, manly adventure”. ${ }^{42}$ Himid’s women, like those of Campos-Pons, are central heroic characters in her reformulated black Atlantic history. Their counter-cultural chart seems to be the cloth between them that invokes the African culture that links blacks across the ocean.

Himid's women are clothed mid-Atlantic, unlike those millions of naked women transported in the Middle Passage, and thus her painting intervenes to reimagine and bring agency to African diasporic women through the feminine material of cloth. As Gikandi discusses, the very act of undressing slaves was part of their dehumanisation:

What is apparent, however, is that when slaves stepped out of the slave ship, they were often naked, or almost naked, and this nakedness did not represent uncleanliness, or even the absence of righteousness, but cultural lack. Slave traders perceived such acts of undressing as a key condition of enslavement. Here, the slavers were not simply reducing slaves to a state of beastliness but also depriving them of the capacity for memory and social connection...clothing was a form of material memory. ${ }^{43}$

Afloat in the Atlantic , Himid's clothed women bring radical agency to the visual economy of the black Atlantic. Gikandi's emphasis on memory and social connection here as communicated by clothing is mirrored by Himid's radical re-imagination. The wider culture had by the 1990s forgotten the history of slavery and its importance to the creation of the modern British state. The trope of forgetting, though, is crucial to Himid’s political praxis.

Ricoeur has talked of the intimate relationship between forgetting, memory and history:

... it is the past, in its twofold mnemonic and historical dimension, that is lost in forgetting.... There is forgetting wherever there had been a trace. But forgetting is not only the enemy of memory and of history. One of the theses to which I am most attached is that there also exists a reserve of forgetting, which can be a resource for memory and for history.... Forgetting is the emblem of the vulnerability of the historical condition taken as a whole. ${ }^{44}$

Like Campos-Pons, Himid mines this reserve of forgetting to imaginatively propose women liberating themselves through movement and like her she uses black women's memory of this routed path out of slavery and imperialism as a means of reinterpreting an 
inadequate historical archive. In Revenge, there are four other canvases which feature two black women "at different moments in history engaged in the planning of strategy", all of which "position black women within a history and as catalysts for changing the course.”45 Himid's poetic prose fragments describe these:

Two women standing ankle deep behind banners in front of cloths shredding maps; fragments float away. Two women sit in a small boat tearing up navigation charts; how many died crossing the water. Two women sit in a theatre box ripping up maps; can the past be replayed. Two women sit at dinner forming strategy; can the future be different better. Two women sit on rugs reliving the history and planning the future; magic carpet fly. ${ }^{46}$

Each of the paintings is described in bare pictorial terms and then its possible meaning figured beyond the canvas. The two women are always at the centre poised between memory and forgetting, proposing alternate histories. The other group of works in Revenge deal with the legacy of the slave ship Zong. In 1781, Captain Luke Collingwood was responsible for the murder of 132 slaves infamously thrown overboard. Collingwood had calculated that the insurers would bear the loss if the slaves died at sea, whereas if, as he feared, they died on board due to a lack of water, the ship owners would have to bear the cost. This pivotal incident in the history of the British slave trade has ramifications far beyond mass-murder, as Ian Baucom discusses in Specters of the Atlantic (2005):

As a truth event of the speculative cultural situation of finance capital, the Zong [is] a symptomatic case - one which identifies not a marginal malfunctioning or local abnormality but the global abnormality of the system as such. ${ }^{47}$

It is because of its symptomatic nature that Himid is drawn to the incident, in a series of small paintings that explore how a memorial to the victims of the Zong, and hence to those of the middle passage, might look. One painting foregrounds the economic calculations which Collingwood undertook before his act of throwing the 'surplus' Africans overboard, and shows that despite his testimony there was clearly enough water to go round.

In 'Memorial to Zong' (1991) Himid, like Wilson, signifies on the imperial tradition of memorialisation through her use of a marble plinth, which instead of a doughty hero of 
empire has on it a white jug with an African head and shoulder portrait on it. This exemplifies the crucial white/black dichotomy in the middle passage, highlighted by the Zong incident's disavowal of the importance of black lives. Water pours from the jug, symbolising the dispersal of African lives in this incident and numerous others, and commemorating the “throwaway people” of the middle passage. ${ }^{48}$ A dark cloth shaped like a sail stands for the countless voyages that have created the forced African diaspora, whilst the water, its droplets formed into numerous closely packed human bodies, represents the human cargo and its survival despite the horrors of the voyage. Himid wants to emphasise the "waste" of lives while celebrating the contribution made by the survivors to diasporan African culture. This waste of lives comes in the context of the physical waste that, according to Hartman (citing Marcel Henaff), continues as a residue from the trade in the slave forts that line the West

\section{African coast:}

In 1972, a team of archaeologists excavated the dungeon.... They identified the topmost layer of the floor as the compressed remains of captives - feces, blood, and exfoliated skin.... Waste is the interface of life and death. It incarnates all that has been rendered invisible, peripheral, or expendable to history writ large, that is, history as the tale of great men, empire and nation. It "evokes the dull ordinary horror of what is vile, worthless and contemptible - a pile of shit". Waste is the remnant of all the lives that are outside of history and "dissolved in utter amnesia." 49

This physical waste ensured that enslaved Africans remained outside history. Himid's memorial seeks to rescue these forgotten people from the status of detritus and give their lives meaning. She might well agree with Giorgio Agamben that "it is not possible to destroy the human, that something always remains. The witness is this remnant”, 50 and indeed in her imaginative conception they do remain, as she stressed to me in a 2003 interview:

I am trying to talk about the waste, the waste of creativity. The excuses that were used for throwing people overboard - that they were too ill to waste water on. I'm talking about the vast expanse of water between yesterday and tomorrow, Africa and the New World and I'm trying to talk also about the place where all those people are now in the water. They are the body of the water now, they are it. It's still there and they are still there and they are still contributing. A moving kind of way of talking about the moving of a people from one place to another... ${ }^{51}$ 
Although twenty years have passed since her 'Memorial to Zong' sketches, Himid has never been asked to make a public memorial based on these wonderful ideas. We are left then with very powerful sketches that promote the making of a memorial to the slave past using sophisticated conceptual ideas around water, waste and accountancy. More than this, though, in promoting a debate about what should be memorialised, Himid, like her contemporary Campos-Pons, has foregrounded artistic and conceptual ideas that contribute to memory studies and provide an interesting analogue to artists responding to the Holocaust who, as Young says, have "made a critique of institutional memory fundamental to their work.",52 Himid, in like fashion, describes how she wanted her memorial to express

.... kind of continuum, where there's a going on, a tomorrow.... I was trying to find a way to talk of a thing that is not there, sort of inside the invisible if you like. I am interested in the politics of representation, how when something is there you can talk about it, write about it, paint it, but when something isn't there what can you say, how can you make something of it, how can it not have been in vain, if you like. So that idea for memorialising came from trying to visualise the invisible. ${ }^{53}$

In visualising the invisible, Himid shares with the other African Atlantic artists I have discussed here a praxis of mining archives and race memory to create works that dynamically comment on histories of slavery and/or posit visions of the future that promote new versions of African Atlantic identity. 


\footnotetext{
${ }^{1}$ Paul Gilroy, The Black Atlantic: Modernity and Double Consciousness (London: Verso, 1993), 15.

${ }^{2}$ Celeste-Marie Bernier, African American Visual Arts (Edinburgh University Press, 2008), 217.

${ }^{3}$ Liz Armstrong, "Like Home: Kara Walker Interview" in No Place Like Home (Minneapolis: Walker Art Centre, 1997), 106

${ }^{4}$ Dominick LaCapra, History in Transit: Experience, Identity, Critical Theory (Ithaca: Cornell UP, 2004), 140
}

${ }^{5}$ Saidiya Hartman, Scenes of Subjection: Terror, Slavery and Self-Making in Nineteenth Century America (Oxford: Oxford University Press, 1997), 51.

${ }^{6}$ Gwendolyn Dubois Shaw, Seeing the Unspeakable: The Art of Kara Walker (Duke University Press: Durham, N.C., 2004). 52.

${ }^{7}$ Hershini Bhana Young,, Haunting Capital: Memory, Text \& the Black Diasporic Body (Lebanon NH: Dartmouth College Press, 2006), 42

${ }^{8}$ Dionne Brand, A Map to the Door of No Return: Notes to Belonging (Toronto: Doubleday Canada, 2001), 31

9 Ibid, 34.

${ }^{10}$ Ibid.

${ }^{11}$ Howardena Pindell, ed., Kara Walker - No, Kara Walker - Yes, Kara Walker? (New York:

Midmarch Arts Press), 107.

${ }^{12}$ Armstrong," Like Home”, 113.

${ }^{13}$ Dubois Shaw, Seeing the Unspeakable, 47.

${ }^{14}$ Ibid, 48.

15 This image is reproduced in Kara Walker, My Complement, My Enemy, My Oppressor, My Love (Minneapolis: Walker Art Centre, 2007), 160.

${ }^{16}$ Ibid, 164.

${ }^{17}$ Marcus Wood, The Horrible Gift of Freedom: Atlantic Slavery and the Representation of Emancipation (Athens GA: University of Georgia Press, 2010), 28-9.

18 Toni Morrison, quoted in Lars Eckstein, Re-Membering the Black Atlantic: On the Poetics and Politics of Literary Memory (Amsterdam: Rodopi, 2006), 228.

${ }^{19}$ Fred Wilson, Mining the Museum (Baltimore:Maryland Historical Society, 1992), 31-32.

${ }^{20}$ Jennifer A. Gonzalez, "Against the Grain: The Artist as Conceptual Materialist” in Doro Globus (ed.), Fred Wilson: A Critical Reader (London: Ridinghouse), 144.

${ }^{21}$ I discuss such guerrilla memorialisations across a range of creative works by African Atlantic artists in my monograph Creating Memorials, Building Identities: The Politics of Memory in the Black Atlantic (Liverpool: Liverpool University Press, 2010).

${ }^{22}$ Maurice Berger "Viewing the Invisible: Fred Wilson's Allegories of Love and Loss" in Doro Globus (ed.), Fred Wilson: A Critical Reader (London: Ridinghouse) , 119-135,130.

${ }^{23}$ Young, Haunting Capital, 33.

${ }^{24}$ Hartman, Scenes of Subjection, 11

${ }^{25}$ Maurice Berger and Fred Wilson, "Collaboration, Museums and the Politics of Display: A Conversation with Fred Wilson in Doro Globus (ed.), Fred Wilson: A Critical Reader (London: Ridinghouse), 154-168, 167-168

${ }^{26}$ James E. Young,, At Memory's Edge: After Images of the Holocaust in Contemporary Art and Architecture (New Haven: Yale University Press, 2000), 180. 
${ }^{27}$ bell hooks, Yearning: Race, Gender and Cultural Politics (London: Turnaround, 1991), 147.

${ }^{28}$ Jean Fisher, "Diaspora, Trauma and the Poetics of Remembrance” in Kobena Mercer (ed.) Exiles, Diasporas and Strangers (London: Iniva, 2008), 190-212, 192.

${ }^{29}$ Sally Berger, "Maria Magdalena Campos-Pons 1990-2001” in Salah Husein and Olu Oguibe Authentic/Excentric Conceptualism in Contemporary African Atlantic Art (Forum for African Arts, 2001), 122-142, 135.

${ }^{30}$ Ibid, 138.

31 Selene Wendt, "Patterns of Remembrance” in Salah M. Hassan and Cheryl Finley (eds.)

Diaspora/Memory/Place (Munich: Prestel, 2008), 230-237, 237.

${ }^{32}$ Derek Conrad Murray and Soraya Murray, "Conversation with Maria Magdalena Campos-Pons" in Salah M. Hassan and Cheryl Finley (eds.) Diaspora/Memory/Place (Munich: Prestel, 2008), 244-248, 247.

${ }^{33}$ Paul Ricoeur, Memory, History, Forgetting, trans. Kathleen Bramley and David Pellauer (Chicago:University of Chicago Press 2004), 161.

${ }^{34}$ Maria Magdalena Campos-Pons, Everything is Separated by Water (New Haven: Yale University Press, 2007), 79.

${ }^{35}$ Berger, "Maria Magdalena”, 125.

${ }^{36}$ Stuart Hall, "Cultural Identity and Diaspora” in Nicholas Mirzoeff (ed.) Diaspora and Visual Cultures: Representing Africans and Jews (London, Routledge, 2000), 21-33, 23

${ }^{37}$ Hudita Nura Mustafa, "Dakar: Memories for Another Middle Passage", ” in Salah M. Hassan and Cheryl Finley (eds.) Diaspora/Memory/Place (Munich: Prestel, 2008), 62-73, 63.

${ }^{38}$ Rice, Alan, 'Exploring Inside the Invisible: An Interview with Lubaina Himid', Wasafiri, 40

(Winter 2003), 21-26, 23.

${ }^{39}$ Ibid, 21-23.

${ }^{40}$ Himid, Revenge, 14

${ }^{41}$ Lubaina Himid "Revenge: A Masque in Five Tableaux." Transatlantic Slave Sites Tour. University of Central Lancashire, March 62001.

42 Jacqueline Nassy Brown, Dropping Anchor, Setting Sail: Geographies of Race in Black Liverpool (Princeton: Princeton University Press), 229.

${ }^{43}$ Simon Gikandi, Slavery and the Culture of Taste (Princeton: Princeton University Press), 215.

${ }^{44}$ Ricoeur, Memory, History, Forgetting, 284.

45 Morgan, “Women Artists and Modernism”, 22.

${ }^{46}$ Himid, Revenge, 14.

${ }^{47}$ Ian Baucom, Specters of the Atlantic: Finance Capital, Slavery and the Philosophy of History (Durham NC: Duke University Press, 2005), 122,

${ }^{48}$ Himid, 2001.

${ }^{49}$ Saidiya.Hartman, Lose Your Mother: A Journey Along the Atlantic Slave Route. New York: Farrar, Straus and Giroux, 2007, 115.

${ }^{50}$ Giorgio Agamben, Remnants of Auschwitz: The Witness and the Archive, trans. Daniel Heller Roazan (New York: Zone Books, 1999), 133-134.

${ }^{51}$ Rice, 'Exploring Inside the Invisible”, 24.

${ }^{52}$ Young,, At Memory's Edge, 10.

${ }^{53}$ Rice, 'Exploring Inside the Invisible”, 24. 